\title{
A review of the distribution and status of Pygmy Palm-Swift Micropanyptila furcata in Venezuela
}

\author{
CHARLES T. COLLINS, THOMAS P. RYAN and RODD KELSEY
}

\begin{abstract}
Summary
Pygmy Palm-Swift Micropanyptila furcata is endemic to the Maracaibo Basin of Venezuela and Colombia. Described by Sutton in 1928, it is still known only from < 30 museum specimens from seven localities, leading it to be included in the first edition of the bird Red Data Book, but not subsequent editions. During a field survey in January 1995 we regularly encountered this species throughout the south-eastern Maracaibo Basin in Venezuela, at elevations from $30 \mathrm{~m}$ to $800 \mathrm{~m}$. We found them in a variety of habitats including cleared pastures, cropland, open forest and rural towns, and observed them near mature cultivated palms, which represented nesting and roosting substrates. Pygmy Palm-Swifts foraged in small groups immediately above the treetops and over grass savannah. As we recorded them at nearly all previously known sites and many additional ones, often in close proximity to human activities and potential sources of disturbance, we suggest that it is not a rare bird and currently does not require special status or conservation efforts.
\end{abstract}

\section{Introduction}

Pygmy Palm-Swift Micropanyptila furcata was described by George Miksch Sutton from two specimens collected by M. A. Carriker, Jr. in 1922 at Guachí, Estado Zulia $\left(9^{\circ} 3^{\prime} \mathrm{N}, 71^{\circ} 30^{\prime} \mathrm{W}\right)$ in the south-eastern Maracaibo Basin of Venezuela (Sutton 1928). Although this new species shared some characteristics with the two other monotypic genera of New World palm-swifts, Reinarda and Tachornis, it did not fit well into either and was placed it its own genus (Sutton 1928). The current trend, started by Lack (1956), to include all three New World palm-swifts in Tachornis is not based on additional information, but only on the commonality of their New World range and general affinity for palms. It has gone largely unnoticed that in 1976, after observing Reinarda and Tachornis in the field, he reversed his view on lumping the three species into one genus (Lack 1976). Despite their common use of palms for nesting substrate, otherwise unique in the New World, and similar nest type and vocalizations (authors' unpubl. data, S. Hilty pers. comm.), we feel a further analysis of the phylogenetic affinities of these palm-swifts is clearly desirable before generic lumping is accepted and herein retain use of Micropanyptila.

Since its description, no studies of the natural history, status, distribution or systematic affiliations of Pygmy Palm-Swift have been conducted. Bond (1956) 
provided a second-hand account of a nest being situated $15 \mathrm{~m}$ above the ground in an unidentified palm near Petrolia, Colombia on 31 July 1951. From 1940 to 1971, 18 additional specimens of this diminutive swift were taken from six localities. Specimens collected at Alturita, near Machiques, in the foothills of the Sierra de Perijá in the western Maracaibo Basin were described as a new subspecies, M. f. nigrodorsalis (Aveledo and Pons 1952). Although there are discernable differences in appearance, later authors have, after examination of additional specimens, treated the species as monotypic (Meyer de Schauensee and Phelps 1978). Unfortunately no body weight was ever recorded for any of these specimens, nor were details given of the habitat where the specimens were collected or the behaviour of the birds themselves. All of the specimens were from lowland or mid-elevation localities in the southern Maracaibo Basin of Venezuela and Colombia (Figure 1).

In the absence of detailed information there has been only speculation about the status of Pygmy Palm-Swift. Its inclusion in the first edition of the bird Red Data Book (Vincent 1966) was based primarily on its limited range and the low number of specimens. A number of species, including Pygmy Palm-Swift, were removed from the second edition (King 1981) even though they were 'still poorly known, [as] there [was] nothing to suggest that they [were] at risk.' This swift is included as a non-threatened but restricted-range species in Endemic Bird Area No. 35 (Caribbean Colombia and Venezuela) by Stattersfield et al. (1998).

Opinions differ on the current abundance of Pygmy Palm-Swift. Relying mostly on older published accounts, Chantler and Driessens (1995) and Chantler (2000) stated that 'with the exception of the White-chested Swift [Cypseloides lemosi] this is apparently the scarcest South American swift. Within [its] small range [it is] distinctly uncommon with very few sites'. Stotz et al. (1996) considered Pygmy Palm-Swift to be of uncertain abundance. However, Hilty and Brown (1986) believed it was found in a rather wide area of adjacent Venezuela and was probably not as rare in Colombia as the one specimen record might suggest. This assertion was based on first-hand observations by themselves and several other naturalists who had travelled through both the Venezuelan and Colombian portions of the south-eastern Maracaibo Basin. Beyond these sources, nothing has recently been published on the distribution, status or habits of this swift. This paper attempts to improve this situation. The aims of our study were: (1) to clarify the range of Pygmy Palm-Swifts in the south-eastern Maracaibo Basin in Venezuela; (2) to describe the habitat types and elevational range of this species; and (3) to evaluate the status of the population and possible conservation measures that might be needed.

\section{Methods}

Our observations were made from 11 to 15 January 1995. We searched from San Cristobal, Estado Táchira, in the south to Valera, Estado Trujillo, in the north (Figure 1). We based our searches in the towns of La Fría, Estado Táchira, El Vigía, Estado Mérida and Betijoque, Estado Trujillo (Figure 1). We travelled Highway I searching along side roads up slope into the western foothills of the Cordillera de Mérida in the eastern Venezuelan Andes and westward into the lowlands bordering Lake Maracaibo. Our searches were mainly conducted from 


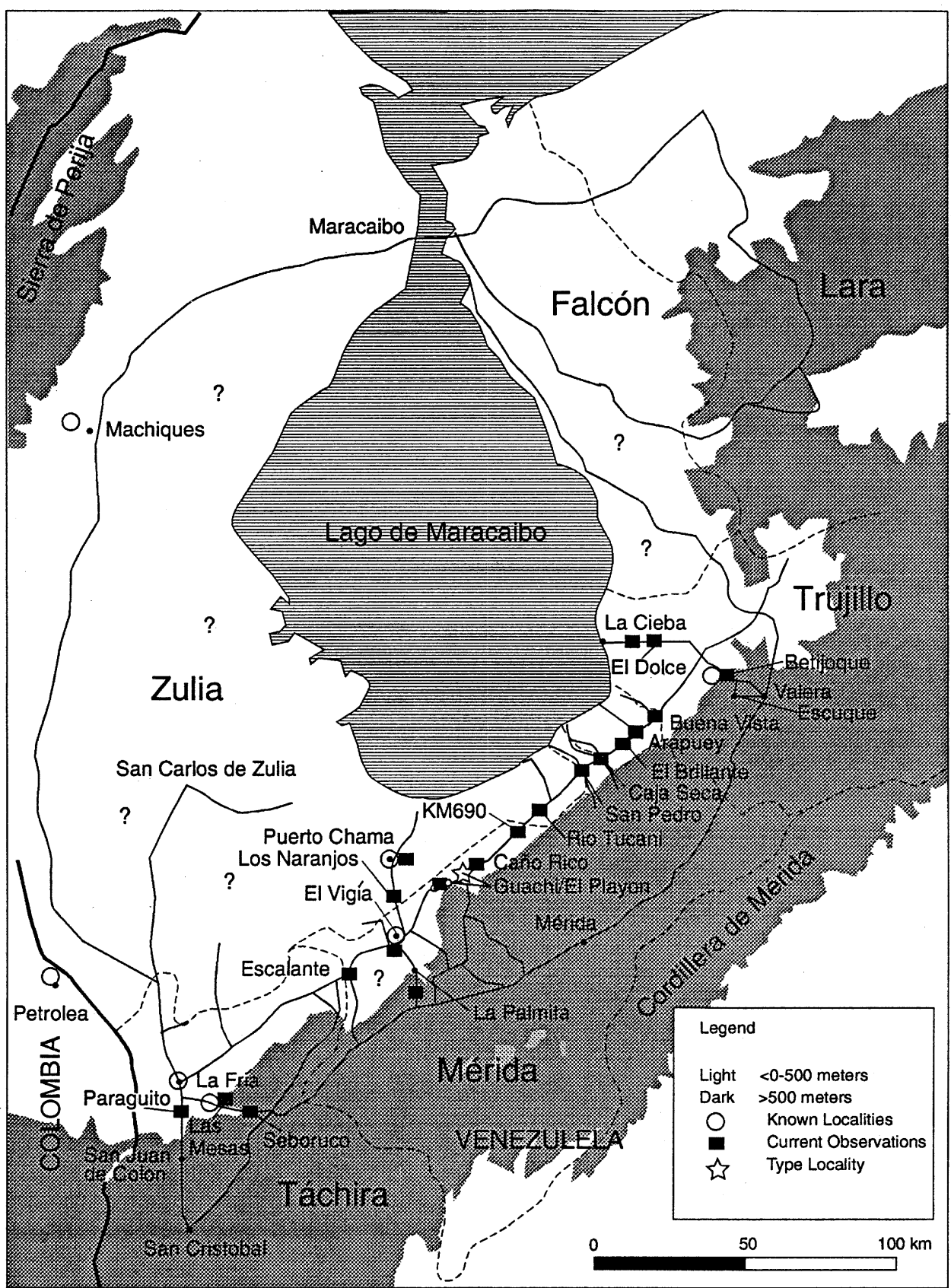

Figure 1. Locations of current and previous sightings and specimen records of Pygmy Palm-Swifts in the south-eastern Maracaibo basin, Venezuela. 
a vehicle moving along both main and dirt roads. The results of a previous survey in this area from 6 to 9 July 1976 (CTC and B. T. Thomas unpubl. data) are also included.

\section{Results and discussion}

\section{Distribution}

In the vicinity of La Fría, Estado Táchira (11-12 January 1995) we found Pygmy Palm-Swifts primarily in the foothills east of La Fría, concentrated near the small town of Las Mesas (elevation 300-430 m) and the small settlement of Paraguito (elevation $600 \mathrm{~m}$ ), which is located $1 \mathrm{~km}$ south-east of the turn off to San Felix. None were encountered during a brief search of the lowlands $<15 \mathrm{~km}$ west of La Fría on January 11. They were also absent from the town of La Fría although they have previously been found there reliably (S. Hilty pers. comm.). It rained during our search along highway 1 north of La Fría on the morning of 12 January and no swifts were located until after the rain stopped at $10 \mathrm{~h}_{40} \mathrm{at}$ the settlement of Escalante (elevation $200 \mathrm{~m}$ ) on the Mérida / Táchira border. Here, 15 swifts were flying around two rows of mature (>15 $\mathrm{m}$ tall) moriche palms Mauritia sp. lining the road to Hacienda El Vegon. They were observed repeatedly entering and exiting nests attached to the downward hanging palm fronds.

From 12 to 14 January 1995, Pygmy Palm-Swifts were found in several locations within the city of El Vigía, Estado Mérida (elevation $200 \mathrm{~m}$ ). Late in the day on 13 January they were observed entering roost sites in a large clump of moriche palms in the grounds of Hosteria El Vigía near the centre of town. In the foothills above El Vigía they were observed moving across a mountain pass above the town of La Palmita (elevation $800 \mathrm{~m}$ ). On 12 and 13 January in the lowlands west of El Vigía, a group of 12-15 swifts were found nesting in a lone fan-leaved palm (probably Copernicia tectorum) in an open pasture near Los Naranjos, Estado Zulia (elevation $60 \mathrm{~m}$ ). This was $21 \mathrm{~km}$ west of Highway 1 along the road to Puerto Chama. Along the same road, on 13 January we observed a second group of 13 Pygmy Palm-Swifts over the Río Chama (elevation $65 \mathrm{~m}$ ) at a bridge $1 \mathrm{~km}$ east of Puerto Chama. Early on 14 January, small flocks (2-14 individuals) were encountered at four sites along Highway 1 between El Vigía and Caño Rico (elevation $200 \mathrm{~m}$ ), including a small group at the type location at Guachí, Estado Zulia. They were regularly observed near human settlements with cultivated moriche palms.

In the vicinity of Betijoque, Estado Trujillo (14-15 January) we observed single individuals and small flocks of up to eight Pygmy Palm-Swifts at five sites between Caño Rico and Caja Seca including San Pedro, El Brillante, and Arapuey (Figure 1). We did not encounter any on a side trip west through the lowlands to Bobures, Estado Zulia, on the shore of Lake Maracaibo. We did, however, see a flock of 15 along a road into the foothills above the town of Buena Vista, Estado Trujillo (elevation $250 \mathrm{~m}$ ). We also encountered several flocks of 10-15 at several places within the town of Betijoque (elevation 575-700 m) on 14-15 January. Two were observed at the settlement of El Dulce (elevation $30 \mathrm{~m}$ ) in the lowlands west of Betijoque on 15 January. We did not encounter any during a search up to $1,300 \mathrm{~m}$ near Escuque in the mountains south-east of Betijoque or on the road east towards Valera on 15 January at the end of our survey. 


\section{Other observations}

On previous trips in the south-eastern Maracaibo Basin, Pygmy Palm-Swifts have been regularly seen in and around the town of La Fría (S. Hilty pers. comm.). During a previous survey over much of the route taken on our 1995 trip, 2 or 3 were observed on 6 July $19764 \mathrm{~km}$ east of La Fría on the road to La Grita as well as at a river crossing below Seboruco (CTC and B. T. Thomas unpubl. data). Between 5 and 10 were observed foraging with other swifts at the Río Tucani on 8 February 1982 (B. T. Thomas pers. comm.). A group of 3 or 4 were also observed 7 July 1976 over Highway 1 at km 690, Estado Mérida, 10 km south of the turn off to El Pino, and a single individual was seen $10 \mathrm{~km}$ south-east of La Ceiba on 8 July 1976 (CTC and B.T. Thomas unpubl. data). 'An impressive concentration of at least 100' of these swifts was seen at the Río Chama bridge on 13 November 1980 (R. Webster and E. Copper in litt.); none were seen at this location on a subsequent visit 9-10 February 1982 (B. T. Thomas pers. comm.). Only 13 Pygmy Palm-Swifts were present there on our most recent visit on 13 January 1995 .

It is unlikely that there is any pronounced seasonal movement of Pygmy PalmSwifts and none has been recorded for the other New World palm-swifts. However, there may be day-to-day movements to exploit localized differences in insect prey resources. This probably accounts for most of the variability in the detection of Pygmy Palm-Swifts at various locales.

In summary, Pygmy Palm-Swifts have been observed in small groups of up to 15 individuals at elevations from $30 \mathrm{~m}$ to $800 \mathrm{~m}$ in a wide variety of locations in the south-eastern Maracaibo Basin. They have most often been found in association with palms, and particularly moriche palms. Pygmy Palm-Swifts have often been found to associate with human activities, ranging from business districts of moderate sized towns to rural settlements, ranches and agricultural areas. Much of the region around Machiques similarly has been extensively cleared for human activities and pastureland (Hitchcock 1954).

Further survey work is necessary to define the northern limit of Pygmy PalmSwift in the eastern Maracaibo Basin and also its range and status in the less visited south-western part of the basin. At present it is only assumed that these swifts are equally widespread there and that their range is contiguous with the population documented at Alturita (Aveledo and Pons 1952) in the north-western part of the basin. We hypothesize that the range of the Pygmy Palm-Swift is limited in the north by the more xeric areas of Estados Trujillo and Zulia where the habitat grades into 'Bosque muy seco tropical' (very dry tropical forest; Ewel and Madriz 1968) and by the higher elevation forests of the Andes and Sierra de Perijá to the east, south and west.

\section{Habitat}

The climax vegetation of much of the northern Maracaibo Basin lowlands is classified as 'Bosque seco tropical' (dry tropical forest) and 'Bosque húmido tropical' (humid tropical forest) in the wetter southern lowlands and foothills (Ewel and Madriz 1968). However, the majority of the lowland regions west of Highway 1 through which we travelled consisted of cleared pastures and farmland with 
sparse, remnant, large buttressed trees and occasional rows of cultivated palms. In these areas we frequently found Pygmy Palm-Swifts very near human habitation, especially when associated with cultivated palms.

The foothill regions east of the wet lowlands were dominated by a combination of second growth deciduous tropical forest, cleared pastures and farmland. Highway 1 forms a north-south transect route through this region with many small towns and settlements adjacent to it. In this area we again found Pygmy PalmSwifts near human habitation and their associated cultivated palms.

The only time we found Pygmy Palm-Swifts at higher elevations (> $750 \mathrm{~m})$ in the montane region to the east was at a pass above La Palmita. The swifts were flying directly over a ridge at this point and none lingered or appeared to be foraging. This higher region was dominated by second growth tropical deciduous forest and small cultivated fields. It should be noted that the habitat associations recorded here may in part be influenced by the types of land-use in the limited areas we were able to survey from available roads.

\section{Behaviour}

Pygmy Palm-Swifts frequently foraged low, within a few metres of trees, manmade structures and shrubs, often circling isolated trees in open fields. Although we only observed them flying higher than about $30 \mathrm{~m}$ once, over the Río Chama, this behaviour may be more common than we observed, particularly when foraging over forest areas and towns (S. Hilty in litt.) Their flight was very erratic, with frequent changes in direction accompanied by fanning of the deeply forked tail. They flew using rapid, shallow wing-beats followed by brief periods of gliding with their wings held beneath the horizontal plane of the body. On one occasion, when foraging with other swifts, they were observed flying lower than at times when they occurred alone (B. T. Thomas in litt.).

\section{Conservation}

We found Pygmy Palm-Swifts to be widely distributed in small flocks throughout the south-eastern Maracaibo Basin of Venezuela. They were often found near human settlements and on land altered by human activities, suggesting that they may not have been subject to the population declines resulting from forest losses and habitat fragmentation documented for other species. In fact, it is possible that their numbers may even have been bolstered by planting of widely utilized ornamental palms. Despite its restricted range in the Lake Maracaibo Basin, the population appears healthy and in no immediate danger. We concur with its removal from the bird Red Data Book (King 1981) and agree with Stotz et al. (1996) and Stattersfield et al. (1998) that Pygmy Palm-Swift has a low conservation sensitivity. We do not feel that any special protection or conservation efforts on its behalf are warranted at this time.

\section{Common Name}

The common names Pygmy Swift and Pygmy Palm-Swift have both been used for Micropanyptila furcata. Although Pygmy Swift has mostly been used in recent 
publications (Meyer de Schauensee 1970, Meyer de Schauensee and Phelps 1978, Hilty and Brown 1986, Chantler and Driessens 1995, Chantler 2000) previous authors have used Pygmy Palm-Swift (Bond 1956, Lack 1956, 1976). The latter seems most appropriate in light of its distinctive and close association with palms and its presumed affinities with the two other New World palm-swifts, Antillian Palm-Swift Tachornis phoenicobia and Fork-tailed Palm-Swift Reinarda squamata, with which the Pygmy Palm-Swift may in fact be congeneric.

\section{Acknowledgements}

We would like to thank Miguel Lentino R. and the Collection Ornithologica Phelps for help in arranging for the necessary permits for this study and use of their equipment, and INPARQUES and PROFAUNA for permission to study in Venezuela. Financial support was received from the Pomona Valley Audubon Society, the California State University Foundation and the Department of Biological Sciences. Steve Hilty, Richard Webster, Elizabeth Copper and the late Betsy Trent Thomas kindly allowed us to include their field observations. We are grateful to Ernesto Fernandez B. for his hospitality and assistance and to the many people we met in our travels, all of whom showed us great hospitality. We are particularly indebted to the late Gilberto Perez without whose knowledge, companionship and abilities this study would not have been as successful or enjoyable. We appreciate the helpful comments and corrections by Steve Hilty and another reviewer which improved the manuscript.

\section{References}

Aveledo, R. and Pons A. R. (1952) Aves nuevas y extensiones de distribucion a Venezuela. Nov. Cient. Contrib. Ocas. Mus. Nat. La Salle 7: 7-8.

Bond, J. (1956) Nesting of the Pygmy Palm Swift. Auk 73: 457.

Chantler, P. (2000) Swifts: a guide to the swifts and treeswifts of the world. New Haven, CT: Yale University Press.

Chantler, P. and Driessens, G. (1995) Swifts: a guide to the swifts and treeswifts of the world. Sussex, U.K.: Pica Press.

Ewel, J. J. and Madriz, A. (1968) Zonas de Vida de Venezuela. Caracas: Republica de Venezeula Ministerio de Agricultera y Cria.

Hilty, S. L. and Brown, W. L. (1986) A guide to the birds of Colombia. Princeton, NJ: Princeton University Press.

Hitchcock, C. B. (1954) The Sierra de Perija, Venezuela. Geogr. Rev. 44: 1-28.

King, W. B. (1981) Endangered birds of the world. The ICBP Bird Red Data Book. Washington, DC: Smithsonian Institution Press.

Lack, D. (1956) A review of the genera and nesting habits of swifts. Auk 73: 1-32.

Lack, D. (1976) Island biology illustrated by the land birds of Jamaica. Berkeley, CA: University of California Press.

Meyer de Schauensee, R. (1970) A guide to the birds of South America. Wynnewood, PA: Livingston.

Meyer de Schauensee, R. and Phelps, W. H., Jr. (1978) A guide to the birds of Venezuela. Princeton, NJ: Princeton University Press.

Stattersfield, A. J., Crosby, M. J., Long, A. J. and Wege, D. C. (1998) Endemic Bird Areas of the world: priorities for biodiversity conservation. Cambridge, U.K.: BirdLife International (BirdLife Conserv. Series 7). 
Stotz, D. F., Fitzpatrick, J. W., Parker, T. A., III and Moskovits, D. K. (1996) Neotropical birds: ecology and conservation. Chicago, IL: University of Chicago Press.

Sutton, G. M. (1928) A new swift from Venezuela. Auk 45: 135-136.

Vincent, J. (1966) IUCN's Red Data Book, 2. Aves. Morges, Switzerland: IUCN.

CHARLES T. COLLINS, ${ }^{1}$ THOMAS P. RYAN ${ }^{2}$ and RODD KELSEY ${ }^{3}$

Department of Biological Sciences, California State University, Long Beach, CA 90840, USA.

${ }^{1}$ Author for correspondence.

${ }^{2}$ Now at H. T. Harvey and Assoc., 3150 Almaden Expresway, Suite 145, San Jose, CA95118, USA.

${ }^{3}$ Now at LSA Associates, 1578 Park Place, Pt. Richmond, CA 94801, USA.

Received 10 October 2001; revision accepted 7 February 2002 